\title{
Use of simulation in the rehabilitation of an anesthesiologist injured in the workplace
}

\author{
Pilar Hernández-Pinto, MD • María V. Martínez-Fernández, PT, CHT • \\ Rosa Ayesa-Arriola, PsyD, PhD · Jose M. Maestre, MD, PhD (i)
}

Received: 10 December 2018/Revised: 25 February 2019/Accepted: 5 March 2019/Published online: 18 March 2019

(C) Canadian Anesthesiologists' Society 2019

\section{To the Editor,}

A major traumatic hand injury can lead to profound functional disability, psychologic distress, and prolonged rehabilitation for an anesthesiologist. Hand reconstruction and early rehabilitation are the cornerstones of treatment. Clinical simulation to replicate the specific clinical work demands was reported to accelerate return to work. Nevertheless, these approaches are focused on physical capabilities, ignoring that psychologic aspects have a relevant influence on recovery. ${ }^{1}$ One-third of hand injured patients have to change work or retire early, and they were more often re-injured at work. ${ }^{2}$

We studied the use of clinical simulation for hand therapy (HT) after thumb autograft in an anesthesiologist, providing psychologic, physical, and functional measures during the process. We expected this strategy would facilitate readaptation to clinical demands and would be effective for an early and safe return to work.

A 42-yr-old, right-hand-dominant anesthesiologist (consenting to this report) who accidentally trapped the thumb of the right hand in a surgical table underwent a partial toe-to-hand autograft to preserve functionality. At week 14 after surgery, simulation was introduced instead of

P. Hernández-Pinto, MD

Anesthesiology Department, Hospital Virtual Valdecilla, Santander, Spain

M. V. Martínez-Fernández, PT, CHT

Hand Therapy, Hospital Ramón Negrete - Mutua Montañesa, Santander, Spain

R. Ayesa-Arriola, PsyD, PhD

Psychiatry Department, Hospital Universitario Marqués de Valdecilla, IDIVAL-CIBERSAN, Santander, Spain

J. M. Maestre, MD, PhD ( $)$

Education Department, Hospital virtual Valdecilla, Santander, Spain

e-mail: jmmaestre@hvvaldecilla.es a regular HT regimen that would have included meaningful activities of daily life and exercises that resemble general job activities. The patient practiced with simulated anesthetic tasks (including endotracheal intubation, bagmask ventilation, epidural and subarachnoid anesthetic techniques, pushing medications, and peripheral and central catheter insertion) and clinical scenarios involving general anesthesia with difficult ventilation and intubation. The patient underwent eight simulation sessions on alternate days for three weeks.

The patient described her emotions and feelings about returning to work. She was afraid of getting injured again, was uncertain about putting patients at risk, and suffered from lack of self-confidence in performing tasks with the same dexterity as before the injury. Simulation practice enabled a positive mental transition from the question "Will I be able to perform as before?" to the discovery of "I can do more than I thought" (Table).

The simulation period finished at week 16. Anxiety, self-confidence, subjective quality of life, subjective disability and symptoms of the hand, and quantitative physical assessments showed significant improvement. The patient resumed clinical duties at week 17, and all assessments remained unchanged one month later.

Return to work depends on psychosocial factors, such as postinjury depression, maladaptive thoughts (like catastrophic thinking or kinesiophobia), anxiety, posttraumatic stress disorder, and emotional distress. ${ }^{3}$ Therefore, simulation may have helped the injured anesthesiologist to train her mind to distinguish situations of clear danger and harm, decrease avoidance coping strategies, limit fears of re-injury, disability and anxiety, and seek out corrective learning experiences that are empowering and might increase quality of life.

It has been suggested that the first six months after a workplace injury may be a window of opportunity to screen for psychosocial symptoms and to provide the 
Table Emotions and feelings evolution before, during, and after the simulation sessions

\begin{tabular}{|c|c|c|c|c|}
\hline Before simulation & $1^{\text {st }}$ day & $2^{\text {nd }}$ day & $3^{\text {rd }}$ to $7^{\text {th }}$ day & $8^{\text {th }}$ (last) day \\
\hline $\begin{array}{l}\text { I'm scared about not } \\
\text { being able to perform } \\
\text { the job tasks }\end{array}$ & $\begin{array}{l}\text { I realize I can do more than I } \\
\text { thought } \\
\text { Will I be able to perform as } \\
\text { before? }\end{array}$ & $\begin{array}{l}\text { I need less time to } \\
\text { perform tasks }\end{array}$ & $\begin{array}{l}\text { I continue to perform } \\
\text { tasks faster }\end{array}$ & I realize I can really perform tasks \\
\hline $\begin{array}{l}\text { I'm scared about getting } \\
\text { injured again }\end{array}$ & $\begin{array}{l}\text { I can focus attention on my } \\
\text { physical sensations }\end{array}$ & $\begin{array}{l}\text { I focus attention on } \\
\text { tasks, not on } \\
\text { physical sensations }\end{array}$ & $\begin{array}{l}\text { I can practice dexterity, } \\
\text { strength, and speed }\end{array}$ & \\
\hline $\begin{array}{l}\text { I have a lack of self- } \\
\text { confidence and I need } \\
\text { self-reassurance }\end{array}$ & $\begin{array}{l}\text { I am noticing palpitations...I } \\
\text { am frustrated }\end{array}$ & $\begin{array}{l}\text { Despite some pain, I } \\
\text { am gaining self- } \\
\text { confidence }\end{array}$ & $\begin{array}{l}\text { I continue to gain } \\
\text { confidence }\end{array}$ & $\begin{array}{l}\text { I can complete all required } \\
\text { maneuvers successfully }\end{array}$ \\
\hline $\begin{array}{l}\text { I'm afraid about putting } \\
\text { patients at risk }\end{array}$ & I am able to perform tasks & & $\begin{array}{l}\text { I have discovered new } \\
\text { ways to perform tasks } \\
\text { without pain }\end{array}$ & $\begin{array}{l}\text { I now consider clinical cases and } \\
\text { choose alternatives to cope with } \\
\text { difficulties in advance }\end{array}$ \\
\hline $\begin{array}{l}\text { I don't want to be the } \\
\text { centre of my } \\
\text { colleagues' attention }\end{array}$ & $\begin{array}{l}\text { This is a safe environment to } \\
\text { practice...no one } \\
\text { observing...no hurries }\end{array}$ & & & \\
\hline
\end{tabular}

necessary support to those who need it. ${ }^{4}$ Simulation in the patient was applied before that mark.

Sahin reported the mean duration of sick leave following severe hand injuries was $202 \pm 145$ days. While 56 of 79 patients (71\%) returned to their previous work, 23 (29.\%) patients had to leave their jobs. ${ }^{5}$ The patient in this study returned to work 145 days after surgery.

Aesthetic results, higher education, socioeconomic status, self-efficacy traits, optimistic expectations, or team coordination may have also affected recovery.

This case shows the increasing confidence of the anesthesiologist in both their skills and time-to-task using simulation as part of the rehabilitation process after hand injury. We encourage our readers to consider the use and study of simulation in supporting return to work after other injuries or medical leaves of absence.

Acknowledgements The manuscript was edited by Nature Research Editing Service.

Conflicts of interest The authors have no conflicts of interest to declare or financial disclosures related to the work under consideration for publication. Hospital Virtual Valdecilla (Santander, Spain) is a simulation centre with the mission of improving patient safety by means of expert training and the development of healthcare professionals. It is a nonprofit, educational, charitable organization that offers instructor and clinical training courses with tuition.
Editorial responsibility This submission was handled by $\mathrm{Dr}$. Gregory L. Bryson, Deputy Editor-in-Chief, Canadian Journal of Anesthesia.

Funding This research did not receive any specific grant from funding agencies in the public, commercial, or not-for-profit sectors.

\section{References}

1. Suarez, C, Maxide J, Szyld D, Maestre JM. Anesthesia simulatorbased functional capacity evaluation of an anesthesiologist after radial fracture: a case report. A A Pract 2018; 10: 133-5.

2. Rosberg HE. Disability and health after replantation or revascularisation in the upper extremity in a population in southern Sweden - a retrospective long time follow up. BMC Musculoskelet Disord 2014; 15: 73.

3. Zale EL, Ring D, Vranceanu AM. The future of orthopaedic care: promoting psychosocial resiliency in orthopaedic surgical practices. J Bone Joint Surg Am 2018; 100: e89.

4. Carnide N. Feelings of depression after a physical work injury. Six-month period after injury a potential "window of opportunity" to identify and address mental health problems. Visions 2016; 11 : 8-10.

5. Sahin F, Akca H, Akkaya N, Zincir OD, Isik A. Cost analysis and related factors in patients with traumatic hand injury. J Hand Surg Eur 2013; 38: 673-9.

Publisher's Note Springer Nature remains neutral with regard to jurisdictional claims in published maps and institutional affiliations. 